\title{
Intravitreal ranibizumab and bevacizumab for the treatment of nonsubfoveal choroidal neovascularization in age-related macular degeneration
}

\author{
Ranibizumab e bevacizumab intravítreo no tratamento da neovascularização \\ de coróide extrafoveal da degeneração macular relacionada à idade
}

\author{
Aaron Brock Roller ${ }^{1}$ \\ Miguel Hage Amaro²
}

Department of Ophthalmology, University of Iowa Hospitals and Clinics, Iowa City, IA - USA.

Department of Ophthalmology, University of Iowa Hospitals and Clinics, Iowa City, IA - USA.

${ }^{2}$ Department of Ophthalmology, Federal University of São Paulo - UNIFESP, São Paulo (SP) - Brazil.

Correspondence address: Aaron Brock Roller. Department of Ophthalmology University of Iowa 200 Hawkins Drive - Iowa City, IA 52242 USA

E-mail: aaron-roller@uiowa.edu

Recebido para publicação em 11.09.2008

Última versão recebida em 27.09.2009

Aprovação em 29.09.2009

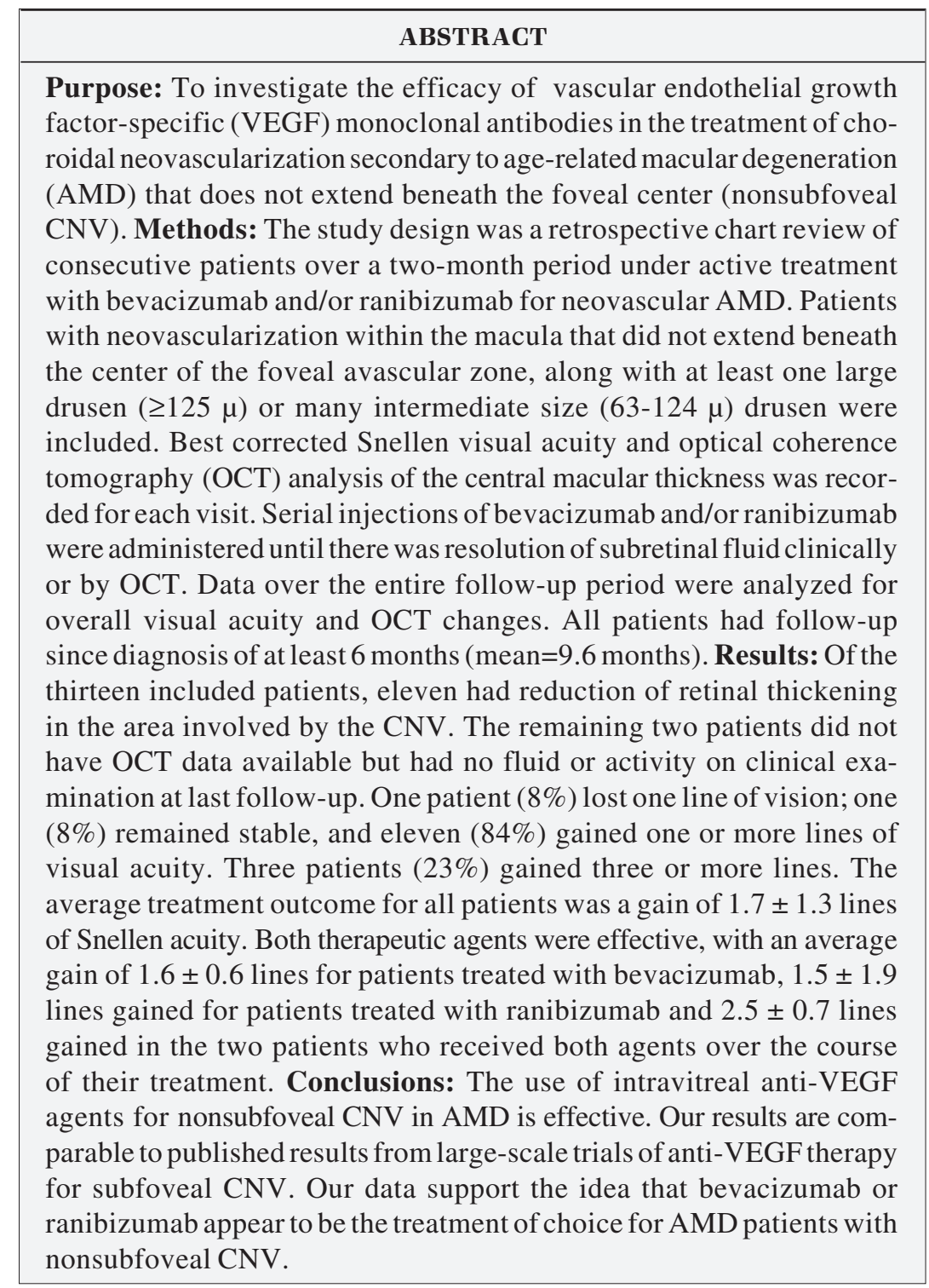

Keywords: Choroidal neovascularization/drug therapy; Macular degeneration/drug therapy; Antibodies, monoclonal; Angiogenesis inhibitors; Visual acuity 
678 Intravitreal ranibizumab and bevacizumab for the treatment of nonsubfoveal choroidal

neovascularization in age-related macular degeneration

\section{INTRODUCTION}

Landmark studies have shown that the vascular endothelial growth factor-specific (VEGF) monoclonal antibodies bevacizumab and ranibizumab are currently the best treatments for patients with age-related macular degeneration (AMD) and subfoveal choroidal neovascularization $(\mathrm{CNV})^{(1-6)}$. Except for a single case report, the studies reported on patients whose neovascularization extended beneath the center of the foveal avascular zone ${ }^{(7)}$.

The Macular Photocoagulation Studies showed that laser photocoagulation was effective in reducing vision loss in pa- tients with extrafoveal CNV ( $\geq 200 \mu \mathrm{m}$ from the foveal center) and juxtafoveal CNV (1-199 $\mu \mathrm{m}$ from the foveal center), but the effect was limited to eyes with classic CNV lesions ${ }^{(8-11)}$. Problems with thermal laser treatment include damage to the fovea and a high recurrence rate of CNV after treatment. Thermal laser treatment can however potentially eradicate CNV, preventing the need for repeated injections of a VEGF inhibitor. Evidence for the use of PDT for the treatment of extrafoveal and juxtafoveal CNV associated with AMD has also been published, but is limited and has had highly variable results ${ }^{(12-15)}$.

AMD patients with non-subfoveal CNV need prompt treatment to avoid macular damage from fluid, hemorrhage, or scar-
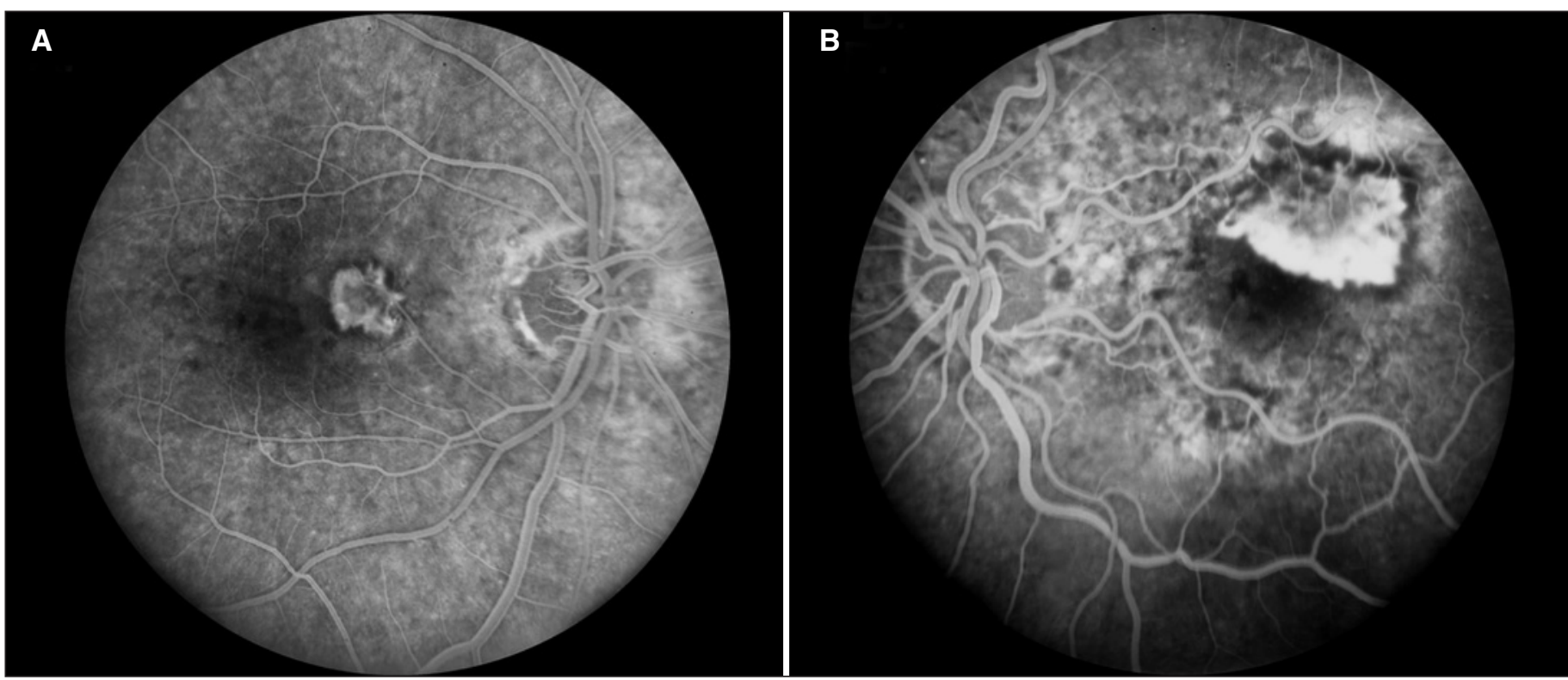

Figure 1 - (A) Extrafoveal CNV, patient number 6; (B) Juxtafoveal CNV, patient number 13

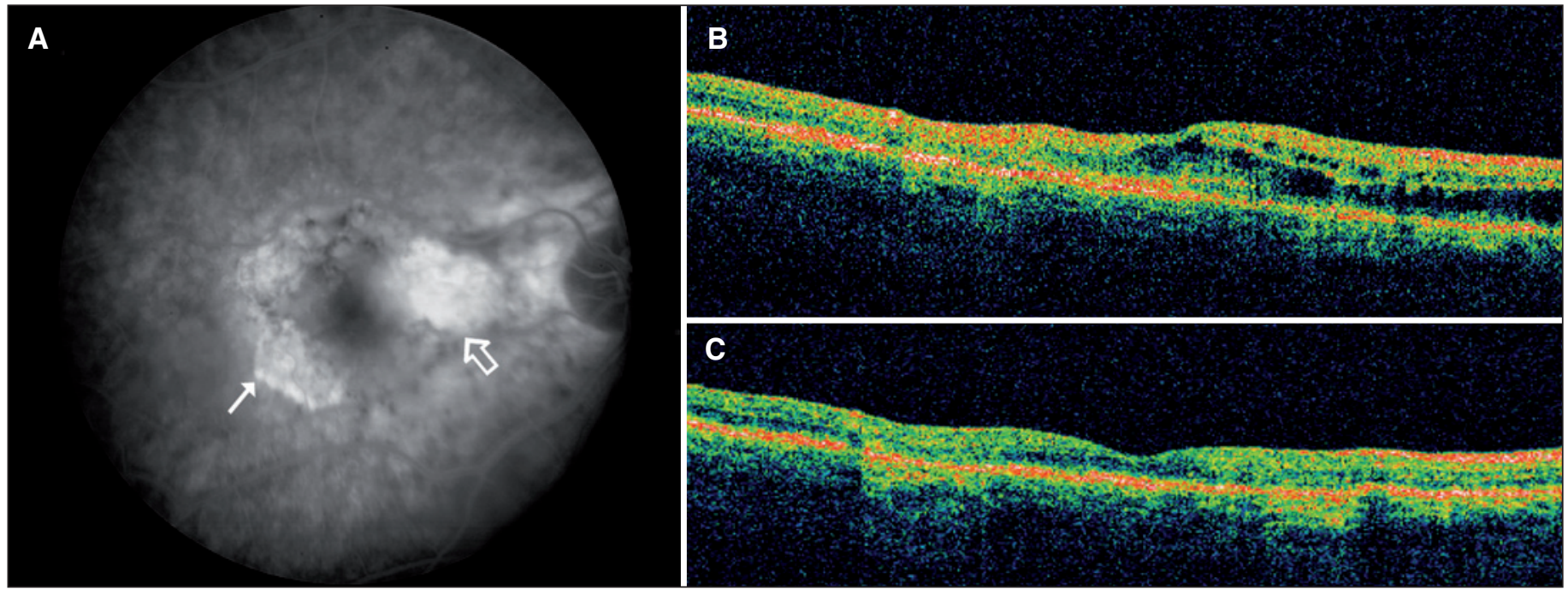

Figure 2 - (A) Fluorescein angiogram of study patient number 1 with classic extrafoveal CNV nasal to fovea (large arrow) in eye with atrophy temporally (small arrow); (B) Intraretinal fluid demonstrated by OCT prior to treatment; (C) OCT of same macular cross-section during treatment with ranibizumab demonstrating resolution of intraretinal fluid 
ring from extension of the CNV into the fovea. Anti-VEGF therapy offers the promise of effectively treating the neovascular process while causing less damage than thermal laser. Herein we present data from a series of patients with AMD and vision loss from CNV that did not extend beneath the fovea who were treated with bevacizumab and/or ranibizumab. We compare these results with those from the Macular Photocoagulation Studies.

\section{METHODS}

This study was approved by the Human Subjects Review Committee of The University of Iowa Hospitals and Clinics. Patients were collected from the practice of Dr. James Folk at The University of Iowa. Every patient under active treatment with either bevacizumab or ranibizumab for neovascular AMD during the consecutive two month period from May 2008 to June 2008 was potentially eligible. A retrospective chart review was performed for all included patients. Fundus fluorescein angiography (FFA) obtained at the time of initial presentation was reviewed to confirm the diagnosis of AMD and to determine if the choroidal neovascularization extended beneath the center of the fovea. Inclusion criteria included neovascularization within the macula that did not extend beneath the center of the foveal avascular zone (FAZ), along with at least one large drusen $(\geq 125 \mu)$ or many intermediate size $(63-124 \mu)$ drusen. Specific exclusion criteria included: geographic atrophy of the RPE that involved the fovea, fundus changes compatible with myopic degeneration, angioid streaks, chorioretinal scars in the macula which could indicate choroidal inflammatory disease, or history of any previous treatment for $\mathrm{CNV}$ or any other retinal disease in the treatment eye.

The distance of the closest point of either the occult or classic neovascularization to the center of the FAZ was measured in microns using software on the digital photographic system. In general a mid-phase image of the angiogram was used when the neovascularization was completely filled but had not yet leaked sufficiently to obscure its margins. Using criteria from the MPS, choroidal neovascularization was considered to be extrafoveal if its closest point did not extend closer than $200 \mu$ to the center of the FAZ, and was classified as juxtafoveal if the closest point was closer than $200 \mu$ to the center but did not extend under the center of the FAZ. The determination of whether the neovascularization was predominantly classic or occult was made using previously reported criteria ${ }^{(12)}$.

Patients were examined at 4-8 week intervals. At each visit, best corrected Snellen visual acuity was measured and Stratus optical coherence tomography (OCT) was performed and evaluated for the presence of intraretinal or subretinal fluid. The central macular thickness as determined by OCT was recorded. Repeat injections were performed until no subretinal or intraretinal fluid was seen on the OCT, at which time they were considered an "anatomic success." Two of the thirteen patients were not followed with OCT imaging but instead by their symptoms, visual acuity, and careful examination of the macula. Per our customary practice to prevent recurrence, all patients were treated with additional injections even after they exhibited resolution of subretinal fluid but the treatment interval was gradually extended to up to 6 months. All patients had at least 6 months of follow-up since diagnosis, and the mean total follow-up time was 9.6 months.

\section{RESULTS}

The review resulted in 13 patients who met the criteria, none of whom were excluded. Mean patient age was $81( \pm 6.8)$ years (Table 1). Seven patients had classic lesions, three had occult and three predominately occult $\mathrm{CNV}$. Of the 13 patients, nine (69\%), had extrafoveal CNVand four, (31\%), had juxtafoveal CNV.

Seven patients were initially treated with an intravitreal injection of $1.25 \mathrm{mg}$ bevacizumab and six were treated initially with $0.5 \mathrm{mg}$ of ranibizumab. Two of the thirteen patients received both agents at different points over the course of their treatment. Mean visual acuity at the time of diagnosis was $20 / 60$ $(\log$ MAR $0.5, \pm 0.28)$.

\begin{tabular}{|c|c|c|c|}
\hline & $\begin{array}{c}\text { Extrafoveal CNV } \\
(n=9)\end{array}$ & $\begin{array}{c}\text { Juxtafoveal CNV } \\
\qquad(n=4)\end{array}$ & $\begin{array}{l}\text { All study patients } \\
\qquad(n=13)\end{array}$ \\
\hline Average age & $81 \pm 7$ & $82 \pm 8$ & $81 \pm 7$ \\
\hline Males & 3 & 2 & 5 \\
\hline Females & 6 & 2 & 8 \\
\hline Mean baseline acuity, logMAR & $0.4 \pm 0.18(20 / 50)$ & $0.7 \pm 0.4(20 / 100)$ & $0.5 \pm 0.28(20 / 60)$ \\
\hline Mean $\mathrm{CMT}^{*}$, microns & $320 \pm 107$ & $293 \pm 30$ & $311 \pm 86$ \\
\hline Mean follow-up, months & $9.7 \pm 6.1$ & $9.5 \pm 3.9$ & $9.6 \pm 5.4$ \\
\hline Mean \# injections & $4.7 \pm 2.6$ & $5.5 \pm 2.6$ & $4.9 \pm 2.6$ \\
\hline Mean OCT change*, microns & $-90 \pm 78$ & $-57 \pm 53$ & $-78 \pm 69$ \\
\hline Mean final acuity, logMAR & $0.17 \pm 0.08(20 / 30)$ & $0.5 \pm 0.14(20 / 60)$ & $0.3 \pm 0.18(20 / 40)$ \\
\hline Mean acuity change, Snellen lines & $+1.7 \pm 1.2$ & $+1.8 \pm 1.7$ & $+1.7 \pm 1.3$ \\
\hline
\end{tabular}


Follow-up ranged from 6-24 months (Mean=9.6). The results were determined from data collected at the last visit. The total number of injections averaged $5( \pm 2.6)$. Eleven patients had reduction of retinal thickening in the area involved by the $\mathrm{CNV}$ and the average central macular thickness reduction after treatment was $78 \pm 69$ microns. The other two patients who did not have OCT data had no fluid or activity on clinical examination. No patient had increased central macular thickness on OCT as of the last follow-up.

At the final follow-up visit, one patient (8\%) had lost one line of vision since the beginning of treatment; one $(8 \%)$ had remained stable, and eleven $(84 \%)$ had gained one or more lines of visual acuity (Table 2). Three patients (23\%) gained three or more lines. The average treatment outcome for all patients was a gain of $1.7 \pm 1.3$ lines of Snellen acuity (Table 1, 2 ). Both therapeutic agents were effective, with an average gain of $1.6 \pm 0.6$ lines for patients treated with bevacizumab, $1.5 \pm 1.9$ lines gained for patients treated with ranibizumab and $2.5 \pm 0.7$ lines gained in the two patients who received both agents over the course of their treatment. This study was too small to calculate statistically significant differences in treatment outcomes between the extrafoveal and juxtafoveal groups, the different CNV lesion types, or between the therapeutic agent used. However, results in all subgroups appeared similarly favorable. All of the 13 patients responded to treatment evident by resolution of retinal or subretinal edema on OCT, visual improvement or clinical resolution of hemorrhage and edema associated with CNV.

\section{DISCUSSION}

The results of this small series of nonsubfoveal CNV in patients with AMD are similar to the visual results of the large MARINA and ANCHOR trials for subfoveal CNV (Table 3). As demonstrated in these trials, both occult and classic neovascularization responded to anti-VEGF therapy in our patients. A slightly greater proportion of our patients had 20/40 or better acuity, probably because there was no subfoveal scarring. We also attempted to compare our results with the MPS studies which used argon laser to treat extrafoveal CNV and krypton red laser to treat juxtafoveal CNV (Table 4). While our results seem favorable, a comparison of different patient groups from different studies and different decades is impossible to interpret in a scientific manner. A prospective, randomized controlled trial is needed to confirm our results.

Bevacizumab and/or ranibizumab was successful at controlling the CNV in all of our study patients. Only one of the 13 patients in this study lost one line of vision, one remained stable,

\begin{tabular}{|c|c|c|c|c|c|c|c|c|c|}
\hline Patient & $\begin{array}{l}\text { CNV } \\
\text { location }\end{array}$ & Type & $\begin{array}{c}\text { VA at } \\
\text { diagnosis } \\
\text { (Snellen) }\end{array}$ & $\begin{array}{c}\text { OCT at } \\
\text { diagnosis* } \\
\text { (microns) }\end{array}$ & Treatment & $\begin{array}{l}\text { Number of } \\
\text { injections }\end{array}$ & $\begin{array}{c}\text { Follow-up } \\
\text { (months) }\end{array}$ & $\begin{array}{l}\text { Final VA } \\
\text { (Snellen) }\end{array}$ & $\begin{array}{c}\text { Final VA } \\
\text { (change) } \\
\text { (lines) }\end{array}$ \\
\hline 1 & Extrafoveal & Classic & $20 / 50$ & 296 & Ranibizumab & 5 & 9 & $20 / 25$ & $(+3)$ \\
\hline 2 & Extrafoveal & Classic & $20 / 40$ & $\mathrm{n} / \mathrm{a}$ & Bevacizumab & 3 & 5 & $20 / 25$ & $(+2)$ \\
\hline 3 & Extrafoveal & Occult & $20 / 50$ & 278 & Bevacizumab & 3 & 5 & $20 / 30$ & $(+2)$ \\
\hline 4 & Extrafoveal & Classic & $20 / 50$ & 281 & Bevacizumab & 3 & 6 & $20 / 40$ & $(+1)$ \\
\hline 5 & Extrafoveal & Pred. Occult & $20 / 60$ & 432 & Both & 3 & 5 & $20 / 30$ & $(+3)$ \\
\hline 6 & Extrafoveal & Classic & $20 / 25$ & 247 & Ranibizumab & 5 & 14 & $20 / 30$ & $(-1)$ \\
\hline 7 & Extrafoveal & Classic & $20 / 50$ & $\mathrm{n} / \mathrm{a}$ & Bevacizumab & 3 & 9 & $20 / 30$ & $(+2)$ \\
\hline 8 & Extrafoveal & Occult & $20 / 50$ & 506 & Both & 11 & 24 & $20 / 30$ & $(+2)$ \\
\hline 9 & Extrafoveal & Occult & $20 / 40$ & 206 & Ranibizumab & 6 & 10 & $20 / 30$ & $(+1)$ \\
\hline 10 & Juxtafoveal & Pred. Occult & $20 / 80$ & 309 & Ranibizumab & 9 & 15 & $20 / 60$ & $(+2)$ \\
\hline 11 & Juxtafoveal & Classic & $20 / 60$ & 310 & Bevacizumab & 3 & 8 & $20 / 50$ & $(+1)$ \\
\hline 12 & Juxtafoveal & Pred. Occult & $20 / 50$ & 248 & Ranibizumab & 4 & 6 & $20 / 50$ & $(0)$ \\
\hline 13 & Juxtafoveal & Classic & $20 / 400$ & 303 & Ranibizumab & 6 & 9 & $20 / 100$ & $(+4)$ \\
\hline
\end{tabular}

\begin{tabular}{|c|c|c|c|c|c|}
\hline & $\begin{array}{l}\text { ANCHOR } \\
\text { (Classic)* }^{*}\end{array}$ & $\begin{array}{l}\text { MARINA } \\
\text { (Occult)* }\end{array}$ & $\begin{array}{c}\text { Study patients } \\
\text { Classic }(n=6)\end{array}$ & $\begin{array}{l}\text { Study patients } \\
\text { Occult }(n=7)\end{array}$ & $\begin{array}{l}\text { All study } \\
\text { patients }\end{array}$ \\
\hline Baseline visual acuity $>20 / 200,<20 / 40$ & $73 \%$ & $72 \%$ & $57 \%$ & $83 \%$ & $69 \%$ \\
\hline Patients with $\leq 3$ lines lost & $96 \%$ & $95 \%$ & $100 \%$ & $100 \%$ & $100 \%$ \\
\hline Patients with $\geq 3$ lines gained & $40 \%$ & $34 \%$ & $14 \%$ & $17 \%$ & $23 \%$ \\
\hline Patients with final VA $20 / 40$ or better & $49 \%$ & $40 \%$ & $71 \%$ & $67 \%$ & $69 \%$ \\
\hline Mean acuity change & +2.1 lines & +1.3 lines & +1.7 lines & +1.7 lines & +1.7 lines \\
\hline
\end{tabular}




\begin{tabular}{|c|c|c|c|}
\hline Visual acuity & MPS-SMDS (extrafoveal)** & MPS-AMDS-K (juxtafoveal) ${ }^{\star \star \star}$ & Study patients \\
\hline Increase or no change* & $57 \%$ & $26 \%$ & $100 \%$ \\
\hline 2-5 line decrease & $28 \%$ & $24 \%$ & $0 \%$ \\
\hline$>5$ line decrease & $15 \%$ & $50 \%$ & $0 \%$ \\
\hline
\end{tabular}

and the other 11 had visual improvement. Seventy percent had 20/40 or better vision at last follow-up. Based on the results of this small series, bevacizumab or ranibizumab appear to be the treatment of choice for AMD patients with nonsubfoveal CNV. The exception could be the patient who has a CNV far from the fovea and who does not want repeated intravitreal injections. Our results are encouraging and deserve further investigation with a larger prospective trial.

\section{ACKNOWLEDGEMENTS}

We thank Dr. James C. Folk, Judith (Gardner) and Donald H. Beisner, M.D. Professor of Vitreoretinal Diseases and Surgery at the University of Iowa in Iowa City, Iowa USA for his generous help with the design and completion of this study.

\section{RESUMO}

Objetivo: Investigar a eficácia dos anti-angiogênicos ranibizumab e bevacizumab injetados intravítreo, no tratamento de pacientes com neovascularização de coróide extrafoveal em degeneração macular relacionada à idade. Métodos: Foram avaliados 13 pacientes com neovascularização de coróide extrafoveal em degeneração macular relacionada à idade do Setor de Retina e Vítreo do Departamento de Oftalmologia da Universidade de Iowa, Estados Unidos, que foram tratados por meio de injeção vítrea de ranibizumab e bevacizumab separadamente, em um período de dois anos. Após as injeções iniciais os pacientes foram acompanhados por exames de OCT e as injeções foram repetidas com 4 a 8 semanas dependendo da presença de líquido sub-retiniano e macular. Resultados: Doze pacientes tiveram ganhos de linhas de visão se comparados com a visão antes do tratamento. Onze pacientes tiveram redução do espessamento retiniano na área envolvida pelo CNV e diminuição e resolução do espessamento macular na sua visita final de avaliação. Um paciente (8\%) perdeu uma linha de visão se comparado à visão prévia ao tratamento. Pacientes tratados com o ranibizumab tiveram em média 2,5 \pm 0,7 ganhos de linhas de visão. Pacientes tratados com bevacizumab tiveram em média 1,6 \pm ganhos de linhas de visão. Conclusão: No tratamento de pacientes com a neovascularização de coróide extrafoveal em degeneração macular relacionada à idade, a injeção vítrea de ranibizumab ou bevacizumab é efetiva e pode ser a opção de escolha.
Descritores: Neovascularização coroidal/quimioterapia; Degeneração macular/quimioterapia; Anticorpos monoclonais; Inibidores da angiogênese; Acuidade visual

\section{REFERENCES}

1. Regillo CD, Brown DM, Abraham P, Yue H, Ianchulev T, Schneider S, Shams N. Randomized, double-masked, sham-controlled trial of ranibizumab for neovascular age-related macular degeneration: PIER Study year 1. Am J Ophthalmol. 2008;145(2):239-48.

2. Bashshur ZF, Haddad ZA, Schakal A, Jaafar RF, Saab M, Noureddin BN. Intravitreal bevacizumab for treatment of neovascular age-related macular degeneration: a one-year prospective study. Am J Ophthalmol. 2008;145(2): 249-56. Comment in: Am J Ophthalmol. 2008;145(5):937; author reply 938.

3. Fung AE, Lalwani GA, Rosenfeld PJ, Dubovy SR, Michels S, Feuer WJ, et al. An optical coherence tomography-guided, variable dosing regimen with intravitreal ranibizumab (Lucentis) for neovascular age-related macular degeneration. Am J Ophthalmol. 2007;143(4):566-83. Comment in: Am J Ophthalmol. 2007; 143(4):679-80.

4. Bashshur ZF, Schakal A, Hamam RN, El Haibi CP, Jaafar RF, Noureddin BN. Intravitreal bevacizumab vs verteporfin photodynamic therapy for neovascular age-related macular degeneration. Arch Ophthalmol. 2007;125(10):1357-61. Comment in: Arch Ophthalmol. 2008;126(9):1314-5; author reply 1315.

5. Rosenfeld PJ, Brown DM, Heier JS, Boyer DS, Kaiser PK, Chung CY, Kim RY; MARINA Study Group_Ranibizumab for neovascular age-related macular degeneration. N Engl J Med. 2006;355(14):1419-31.

6. Brown DM, Kaiser PK, Michels M, Soubrane G, Heier JS, Kim RY, Sy JP, Schneider S; ANCHOR Study Group. Ranibizumab versus verteporfin for neovascular age-related macular degeneration. N Engl J Med. 2006;355(14):1432-44.

7. Mones JM, Lopez MA, Prieto JA, Rodriguez JP. Extrafoveal choroidal neovascularization secondary to wet age-related macular degeneration treated with intravitreal bevacizumab. Ophthalmic Surg Lasers Imaging. 2007;38(3):226-8.

8. Occult choroidal neovascularization. Influence on visual outcome in patients with agerelated macular degeneration. Macular Photocoagulation Study Group. Arch Ophthalmol. 1996;114(4):400-12. Erratum in: Arch Ophthalmol 1996;114(8): 1023.

9. Krypton laser photocoagulation for neovascular lesions of age-related macular degeneration. Results of a randomized clinical trial. Macular Photocoagulation Study Group. Arch Ophthalmol. 1990;108(6):816-24. Comment in: Arch Ophthalmol. 1991;109(5):614-5.

10. Argon laser photocoagulation for neovascular maculopathy. Three-year results from randomized clinical trials. Macular Photocoagulation Study Group. Arch Ophthalmol. 1986;104(5):694-701.

11. Argon laser photocoagulation for senile macular degeneration. Results of a randomized clinical trial. Arch Ophthalmol. 1982;100(6):912-8.

12. Wachtlin J, Stroux A, Wehner A, Heimann H, Foerster MH. Photodynamic therapy with verteporfin for choroidal neovascularisations in clinical routine outside the TAP study. One- and two-year results including juxtafoveal and extrafoveal CNV. Graefes Arch Clin Exp Ophthalmol. 2005;243(5):438-45.

13. Voelker M, Gelisken F, Ziemssen F, Wachtlin J, Grisanti S. Verteporfin photodynamic therapy for extrafoveal choroidal neovascularisation secondary to age-related macular degeneration. Graefes Arch Clin Exp Ophthalmol. 2005; 243(12):1241-6.

14. Frennesson CI. Photodynamic therapy with verteporfin in patients with agerelated macular degeneration and juxtafoveal choroidal neovascularization. Acta Ophthalmol Scand. 2004;82(6):651-5.

15. Blair MP, Apte RS, Miskala PH, Bressler SB, Goldberg MF, Schachat AP, Bressler NM. Retrospective case series of juxtafoveal choroidal neovascularization treated with photodynamic therapy with verteporfin. Retina. 2004;24(4):501-6. 